Studia Slavica Savariensia 2018. 1-2. 32-38

DOI: $10.17668 /$ SSS.2018.1-2.32

Timea Bockovac

(Pečuh, Mađarska)

\title{
O UGROŽENOSTI JEZIKA HRVATA U MAĐARSKOJ
}

Abstract: The destiny of minority languages relies on both subjective and objective factors. Among these factors one can find the process of language (code) switching which can be influenced with strategic linguistic actions like language planning. However, to elaborate certain measures of language preservation it is important to determine the level of vulnerability of the language in question. We do not have enough indicators about the vulnerability of the language of Croats in Hungary. The aim of this work is to, with the help of international classification measures (Fishman, Krauss), determine the current state of the Croatian language on the basis of occurrence, use and transfer in correlation with the number and the age of speakers.

Keywords: Croatian as a minority language, language planning, language revitalization, language vulnerability

Jezično stanje svake manjine ovisi o objektivnim i subjektivnim čimbenicima, o zajamčenim jezičnopravnim okvirima, o odgojno-obrazovnom sustavu kao i o odnosu manjine prema svome jeziku. U ovom kontekstu potrebno je naglasiti kako se pojam jezičnoga planiranja najčešće poistovjećuje s planiranjem korpusa i statusa, a tek se u novijoj teoriji pojavljuje potreba za jezičnim oživljavanjem koji se ostvaruje kao planirani proces, svojevrsna intervencija iza kojeg se kriju jezični pokazatelji date skupine.

Na pitanje u kojoj se mjeri jezik Hrvata u Mađarskoj smatra ugroženim možemo odgovoriti tek nakon provedenih sociolingvističkih istraživanja, kada se ustanovi realno jezično stanje uz pomoć egzaktnih pokazatelja. Pri tome polazište čini određivanje trenutačnoga jezičnog stanja uz pomoć međunarodno razrađenih i prihvaćenih klasifikacijskih mjerila.

Skala koju je sastavio Fishman (1991, citira GÁL 2010:42-45) navodi osam razina na kojima se promatra pojava i uporaba jezika te ovisno o njegovomu omjeru dobivaju se pokazatelji koji upućuju na trenutačno stanje jezične zamjene.

1.razina: jezik se koristi u visokome obrazovanju, ima razrađenu terminologiju, nazočan je u državnoj upravi i u medijima

2.razina: jezik se rabi u mjesnoj upravi i u lokalnim medijima

3. razina: jezik se rabi i izvan jezične zajednice, kao i na radnim mjestima 
4.razina: jezik se rabi u školstvu

5.razina: jezik je nazočan na početnoj razini formalne jezične socializacije (uči se u školama pisanje i čitanje)

6.razina: jezikom se koriste sve tri generacije, predaja jezika se odvija besprekidno

7.razina: $u$ životu zajednice se održavaju priredbe na materinskomu jeziku, ali ne postoji kontinuitet prenošenja jezika među generacijama govornika

8.razina: jezik govore pripadnici starije generacije u izoliranim, ruralnim okruženjima te je vrlo velika vjerojatnost izumiranja jezika

Jezik Hrvata u Mađarskoj se može smjestiti na svaku ljestvicu Fishmanove klasifikacije, ali nije teško zaključiti ni kako je na osmoj razini naveden proces jezične zamjene sve intenzivniji u slučaju onih mjesnih govora čiji su zadnji govornici u visokoj životnoj dobi (ljudi iznad 80 ili 90 godina), kao što je slučaj kod pojedinih naselja Hrvata u Mađarskoj (npr. nekadašnji Semartin u Baranjskoj županiji), a i u onom slučaju kada još postoji izvorni ruralni oblik suživota dokazan je prekid prenošenja jezika kod srednje generacije.

$\mathrm{Na}$ sedmoj razini, navedene priredbe koje se odvijaju isključivo na materinskome jeziku su iznimno rijetke među Hrvatima u Mađarskoj, naime one su najčešće dvojezične.

$\mathrm{Na}$ šestoj razini se javlja kao jamstvo očuvanja jezika predaja istoga od starijih prema mlađima. Vezano za taj pristup se nerijetko navodi kako su mješoviti brakovi uzroci nestanka hrvatskoga jezika u obitelji i prijelaza na dominantni, većinski jezik, međutim što se tiče Hrvata u Mađarskoj to je tek djelomice istražena pojava (detaljnije vidi: HORVÁTH 2005), moja iskustva govore da nije opravdano gubljenje hrvatskoga jezika u slučaju mađarskohrvatskih brakova, niti da je neupitno sačuvanje hrvatskoga u obitelji jezično homogenih (hrvatski-hrvatski) parova.

Csanád Bodó koristi pojam zakašnjele jezične socijalizacije na drugome jeziku, koji se u potpunosti može primijeniti na tijek jezičnoga usvajanja hrvatskoga jezika kod učenika koji pohađaju dvojezične (hrvatsko-mađarske) obrazovne ustanove ili su sudionici obrazovnog programa s pojačanim hrvatskim. Spomenuta formalna jezična socijalizacija može se odnositi i na osobu koja potječe iz hrvatske (narodnosne) zajednice, ali će jezik zajednice savladati tek kasnije u organiziranim, ali izvanškolskim okolnostima (npr.: na jezičnim tečajevima).

Bez obzira što prve četiri razine potpuno podržavaju jezični identitet, nastava na materinskom jeziku ili na dva jezika sama po sebi ne jamči zaustavljanje zamjene jezika, ukoliko jezika više nema u obitelji, gdje bi izvorno trebao imati privilegizirani položaj.

Hrvatski jezik u Mađarskoj se predaje i u školama koje po zakonu mogu održavati narodnosne samouprave odnosno država, raspolažemo materijalima i pomagalima na hrvatskome jeziku, znači jezik se rabi u institucionaliziranim okvirima, ali u javnoj upravi izuzetno skromno. Gledano s aspekta jezičnih 
prava hrvatski se podržava, ali čini se da je odnos zajednice prema očuvanju jezika ravnodušan, dokumentiranost jezika je dobra, stoje nam na raspolaganju normativni udžbenici, međutim malo ima metodičkih priručnika i digitaliziranih nastavnih pomagala.

$\mathrm{Na}$ trećoj razini navedeni uvjeti su ispunjeni u najmanjoj mjeri, odnosno sužavaju se na ona radna mjesta koja su vezana uz odgojno-obrazovni rad ili uz administrativnu djelatnost.

Vezano za drugu razinu na kojoj su naznačeni segmenti visoke politike, medija te javne uprave, pratimo prevlast većinskoga jezika, premda je pravno reguliran način uporabe manjinskoga jezika, ali to iziskuje znatno više truda $i$ zbog toga se smatra atipičnim.

Hrvatski jezik u medijima je zastupljen i aktivan i u određenoj mjeri prati razvojne tendencije (npr. elektronski mediji).

$\mathrm{Na}$ prvoj razini se navodi uporaba jezika u visokome školstvu, poznavajući aktualne brojeve o upisanim studentima možemo zaključiti da je to jedan zaista uži krug govornika te da se osim filologije jedva može proširiti na druge discipline.

Nakon pregleda domene jezika vrijedi promatrati i Kraussovu (2006) tipologiju koja vrjednuje razine jezične predaje:

1. jezik govore sve generacije i veliki dio dječje populacije

2. jezik govore odrasli, odnosno roditelji i njihovi roditelji, ali samo mali broj djece/ govornici imaju pretežito 30 godina ili više

3. jezik govore pripadnici srednje generacije te stariji od njih/ govornici imaju oko 50 godina ili su stariji

4. govornici imaju više od 70 godina

5. govornici imaju 70 godina, a njihov broj je manji od deset

6. ne postoje govornici jezika, jezik je izumro

(citira Grenoble 2006, Grenoble-Whaley 1998, GÁL:2006:59)

U sklopu navedenih 6 kategorija na različitim razinama se javlja jezik Hrvata u Mađarskoj. Ukoliko promatramo međugeneracijsku jezičnu predaju, tada se on nalazi između 2-5 razine, ali je naglašenija 2. razina, tj. jezik govori starija generacija, međutim on se ne prenosi na mlađu uslijed čega hrvatski najčešće nije materinski, nego prvi učeni jezik.

O omjeru govornika se može zaključiti kako na drugoj razini jedna manja skupina govori hrvatski, odnosno uvjetovano zemljopisnim odredištem možda to čini čak i većina, ali primarno se radi o sve manjem broju te o ograničenim formalnim komunikacijskim prostorima na kojima je atipično ravnomjerno korištenje mađarskog i hrvatskog jezika. Uzevši u obzir jezičnu kompetenciju govornika realno je hrvatski jezik staviti između druge i pete razine, međutim za točnije određenje su nam potrebna dodatna sociolingvistička istraživanja.

Prema niže navedenoj klasifikaciji Grenoble i Whaleyja za jezik Hrvata u Mađarskoj nije karakteristična prva odnosno druga razina, on se potisnuo na treću, četvrtu i petu razinu, ili se nalazi između njih u prijelaznoj fazi, znači 
stanje nije točno precizirano, ali nam može poslužiti kao polazište za planiranje daljnjih revitalizacijskih postupaka.

1. Svi pripadnici zajednice imaju potpuno jezično znanje i u govoru i u pismu, manje dominantan jezik je nazočan na svim razinama i u formalnim i u neformalnim situacijama.

2. Pripadnici zajednice na visokoj razini barataju jezikom u svim jezičnim segmentima.

3. Jedan dio zajednice na nekoliko područja u potpunosti se koristi i pisanim i usmenim oblikom manje dominantnog jezika.

4. Jedan dio zajednice se koristi manje dominantnim jezikom u potpunosti, ali su ta područja ograničena.

5. Jedna skupina unutar zajednice raspolaže djelomičnim zanjem jezika, u nekoliko tema su fluentni govornici, ali su područja znatno ograničena (npr.:isključivo se svode na prikaz tradicionalne kulture, priče, pjesme, sakralnosti).

6. Ne postoji funkcionalna uporaba jezika, jezična kompetencija zajednice je svedena na nekoliko riječi. (Gál 2010:168-169)

Nakon prikazanih postupaka klasificiranja hrvatskoga jezika u Mađarskoj potrebno je uzeti u obzir i Kraussov (2006) prognostički pristup:

1. „sigurni” jezici: djeca ih uče kao prvi jezik i to će se i u buduće tako odvijati

2. ugroženi jezici:

a. stabilni jezici: djeca ih još uče kao materinski jezik

b. jezici koji pokazuju znakove propadanja:

i. instabilni jezici: među djecom je mali broj govornika

ii. izrazito ugroženi jezici: jezik ne uspijeva postići prag preživljavanja, djeca ga ne usvajaju kao materinski jezik, najmlađa generacija je generacija roditelja

iii. u teškoj mjeri ugroženi jezici: najmlađi govornici su pripadnici starije generacije, roditelji već nisu u stanju prenošenja jezika

iv. kritično ugroženi jezici: najmlađi govornici su pradjedovi i prabake koji žive u skromnom broju

3. izumrli jezici: nemaju više govornika, nitko ih ne pamti, ne postoji mogućnost jezičnoga dokumentiranja (Krauss, citira ga: Tsunoda 2006: 12, GÁL 2010: 40).

Prema navedenim podacima se sve jasnije ocrtava ugroženost hrvatskoga kao manjinskoga jezika, naime u sklopu određenih kategorija hrvatski jezik pripada među izrazito ugrožene jezike, pogotovo ukoliko se jezik ne prenosi kao materinski. Uvjeti navedeni kod podskupina druge razine se također obistinuju kod hrvatskoga, npr. generacija roditelja kao zadnji aktivni govornici, a opravdano je govoriti i o teškoj ugroženosti ukoliko roditelji više nisu u mogućnosti prenositi jezik svojim potomcima.

UNESCO je 2003. godine razradio okvirni sustav ugroženosti jezika unutar kojeg su određene tri velike kategorije: 
I. Podatci koji se vezuju uz jezik i uz jezični prostor

II. Jezična prava i psihosocijalni aspekti

III. Vrjednovanje jezičnih kompetencija zajednice.

U prvoj kategoriji se razmatraju razine međugeneracijske jezične predaje prema kojem možemo ponovno zaključiti kako hrvatski u većini obitelji nije prvi jezik, najmlađi izvorni govornici su roditelji koji, iako raspolažu znanjem jezika, ne rabe ga s djecom, jezik je najzastupljeniji među starijim govornicima. Po omjeru govornika manjinskoga jezika unutar manjinske zajednice se zaključuje kako se on još koristi kod većeg broja pripadnika manjine, ali tendencije koje prate prostor jezične interakcije svjedoče o sve manjem broju, odnosno o ograničenim i formalnim interakcijama. Ukoliko se uzmu u obzir novonastala jezična područja (npr. novi mediji) svjedoci smo pokušajima prilagodbe, dok o postojanosti ili nedostatku pisanih obrazovnih materijala je razvidno kako je to na najvišoj razini u obrazovanju.

Područja II. kategorije čine jezična prava i jezična politika pojedine države, na kojoj se ističe dodatna potpora manjinskog jezika, međutim odnos zajednice prema vlastitom jeziku nije isti, velik dio zajednice je ravnodušan prema očuvanju jezika te se manji dio uključuje intenzivnim radom u sprječavanje jezične zamjene. Dokumentiranost jezika se smatra dobrim zbog postojećih deskriptivnih gramatika, rječnika i antologija.

Vrjednovanje jezičnih kompetencija (III. kat.) se vrši prema analizi individualnih govornika, a tu se javljaju najveće razlike od govornika koji su fluentni do onih koji jezik rabe u vrlo skromnoj mjeri isključivo $u$ familijarnom okruženju.

Osim prikazanih klasifikacijskih modela u kontekstu jezičnoga razvijanja, treba uzeti u obzir i pokazatelje etnolingvističke vitalnosti jezika koje se i u slučaju Hrvata u Mađarskoj promatraju na tri razine, a to su status jezika, demografski podaci zajednice te institucionalizirana potpora (pl. Giles i suradnici 1977 Bodó 2004b; Landry Allard 1994a, 1994b; Molnár-Bodrogi 2008; Yagmur Kroon 1998 citira GÁL 2010: 56).

Vezano za status jezika ukoliko je jezik službeno priznat te je gospodarski i društveni prestiž njegovih govornika visok, tada se on smatra manje ugroženim, međutim manjinski jezici uživaju status službenoga jezika, ali to ne utječe automatski na njihov prestiž u društvu, a nažalost niti na odnos manjinskih govornika prema svome jeziku.

O demografskim pokazateljima se najtočnija slika dobiva iz podataka nataliteta $\mathrm{i}$ mortaliteta te podataka o mješovitim brakovima, odnosno o zemljopisnim odredištima.

O broju Hrvata u Mađarkoj raspolažemo podacima popisa stanovništva, ali ti brojevi iziskuju kompleksnu analizu u suodnosu s ostalim sociolingvističkim segmentima kako bi bilo moguće objasniti aktualne tendencije koje svjedoče o 
sve većem broju pripadnika hrvatskoj manjini, a o sve manjem broju izvornih govornika hrvatskoga jezika ${ }^{1}$.

Vitalnost jedne skupine može biti subjektivna ili objektivna, velika, prosječna, mala i prirodno je „kako skupine s velikom vitalnosti tj. s visokim statusom i povoljnim demografskim obilježjima s puno veće šanse će očuvati svoj jezik" (Giles, Bourhis és Taylor, citat: BARTHA 1999: 134, prijevod autora).

Europska Unija „...zauzima stajalište da je politika revitalizacije jezika dugoročan napor koji se mora temeljiti na raznovrsnom i koordiniranom planiranju aktivnosti na različitim područjima, a posebno u obrazovanju (s predškolskim $i$ osnovnoškolskim obrazovanjem kao stvarnom prednošću, zajedno $s$ roditeljskom podukom na samom jeziku), upravi, medijskim programima (također s mogućnošću uspostave i razvoja radijskih i televizijskih postaja), umjetnostima i svim područjima javnog života, podrazumijevajući da potrebni resursi budu dostupni na dulji rok; zauzima stajalište da je potrebno pružiti potporu za izradu takvih programa, za razmjenu dobrih praksi među jezičnim zajednicama i za uvođenje postupaka ocjenjivanja" ' .

Daljnji čimbenici koji utječu na jezičnu vitalnost mogu biti na makro i mikro razini. U slučaju Hrvata u Mađarskoj na makro razini se javlja nacionalnost, jezično pravni okviri, obrazovna politika, dok na mikro razini treba uzeti u obzir odnos zajednice prema svom jeziku odnosno prema većinskome jeziku, ljudske resurse, kvalitetu manjinske elite i omjer onih govornika koji raspolažu visokom jezičnom kompetencijom.

Hrvati u Mađarskoj raspolažu s izgrađenom odgojno-obrazovnom infrastrukturom u kojoj je velika koncentracija državne potpore, ali je jezična učinkovitost sprovedenih programa nedovoljno istražena.

Odluke vezane za jezik osim jezične dimenzije imaju i društvenu i ideološku dimenziju. Ukoliko se prihvati teza Grenoble i Whaleyja (2006) prema kojoj broj govornika je važan, ali ne i mjerodavan, što se budućnosti jezika tiče moramo uzeti u obzir i druge čimbenike npr. globalizaciju, gospodarsku integraciju, funkcionalni gubitak jezika u prostoru, jezičnu politiku i obrazovnu politiku, postojeće financijske izvore (GÁL 2010: 60-63) kako bi se svi ti rezultati mogli ugraditi u daljnja revitalizacijska nastojanja.

Zaključno se može reći da je u hrvatskoj zajednici u Mađarskoj djelomice završena jezična zamjena, a razlog tome može biti i postupno sužavanje onih jezičnih prostora na kojima je nekoć bio jezik aktivan, npr.: unutar obitelji, ali nailazimo na primjer jezičnoga izumiranja i u slučaju naselja koje se $u$

\footnotetext{
${ }^{1}$ broj Hrvata 2001:15 594, 2011:23 0561, broj govornika hrvatskoga kao materinskoga jezika 2001:14323, 2011: 13716 (izvor:www.nepszamlalas.hu/hun.kotetetk.htmel pristupljeno 08.07.2018.g.)

2 http://www.europarl.europa.eu/sides/get(pristupljeno 09.10.2018.g)
} 
potpunosti napušta, dolazi do razilaženja govornika i do generacijskog prekidanja predaje jezika, kao i do izumiranja izvornih govornika. Međutim hrvatski jezik je još uvijek prvi jezik jednog užeg kruga govornika, rabi se u obiteljskom i prijateljskom krugu. Istodobno je potrebno jačanje svijesti o jezičnome identitetu pogotovo kod mlađe generacije što čini opravdanim izvršenje revitalizacijskih mjera, pri kojih se treba uzeti u obzir kako je „Utjecaj obrazovanja je na revitalizaciju iznimno važan jer su neposredno povezani: institucinalizirano obrazovanje je temelj uspješnoj jezičnoj podršci, odnosno jezičnome oživljavanju, međutim strategije centraliziranog nacionalnog obrazovnog sustava se rijetko mogu u potpunosti primijeniti na sve lokalne slučajeve $i$ jezike, te stoga i ne ispunjavaju obrazovne potrebe. Potrebno je naglasiti da oni programi koji se isključivo temelje na institucionaliziranom obrazovanju najčešće donose male, nevažne rezultate, naime jačaju samo jednu jezičnu funkciju" (GÁL 2010:61, prijevod autora).

Istraživački pristup prema manjinskome hrvatskome jeziku bi trebao ujediniti suvremene i tradicionalne jezikoslovne metode te pratiti novonastala područja poput ekolingvistike kako bi saznali što više o jezičnoj vitalnost svoga jezika i razradili odgovarajuća pomagala za jezičnu revitalizaciju koja se čini sve potrebnijom.

\section{Literatura}

BARTHA 1999 = BARTHA CS. A kétnyelvüség alapkérdési (beszélők és közösségek) Budapest: Nemzeti Tankönyvkiadó, 1999.

BODÓ 2016 = BODÓ CS. Nyelvi ideológiák és különbségek. Kolozsvár: Nemzeti Kisebbségkutató Intézet, 2016.

GÁL $2010=$ GÁL N. A nyelvi revitalizáció. Elméletek, módszerek, lehetőségek. Kolozsvár: Szabó T. Attila Nyelvi Intézet - Anyanyelvápolók Erdélyi Szövetsége, 2010.

HORVÁTH $2005=$ HORVÁTH S. A grádistyei horvátok XVI-XX.századi asszimilációjának példái // Kisebbségkutatás 2. 181-193.

http://www.europarl.europa.eu/sides/get (pristupljeno 09.10.2018.g)

Language Vitality and Endangerment, UNESCO 2003. http://www.unesco.org/new/fileadmin/MULTIMEDIA/HQ/CLT/pdf/Languag e_vitality_and_endangerment_EN.pdf (pristupljeno 11.10.2018.g.) 